\title{
Occupational Safety Culture of Accommodation Sector Employees in Balıkesir Province: NOSACQ-50 Survey
}

\author{
Müge Ensari Özay*, Arda Yılmaz, Rüştü Uçan \\ Uskudar University, Faculty of Health Sciences, 34662 Istanbul, Turkey \\ *muge.ensariozay@uskudar.edu.tr $\left(\mathrm{D}\right.$, arday1989@gmail.com ${ }^{\mathrm{D}}$, rustu.ucan@uskudar.edu.tr $(\mathrm{D}$ \\ Received date: 09.10.2020, Accepted date: 26.12.2020
}

\begin{abstract}
This research aims to examine the level of safety culture in the accommodation sector and the factors that affect it. In this study, NOSACQ-50 questionnaire was applied as a measurement tool to 200 accommodation sector employees to investigate occupational safety culture of the participants. Six research questions were analyzed. The collected data were evaluated with the SPSS 25 program. Independent t tests and one-way variance analysis were applied to determine the significance level of the relationship between the participants' responses to the questionnaire and the research questions. The results from the safety culture questionnaire were addressed under 3 categories: the occupational health and safety (OHS) awareness of management, the OHS awareness of employees, and the OHS training knowledge of employees. A statistically significant positive correlation was found between the management's OHS awareness and the employees' OHS awareness scores. Besides, a statistically significant relationship was determined between employees' occupational health and safety awareness and their professional experiences.
\end{abstract}

Keywords: Accommodation sector, NOSACQ-50 survey, occupational safety, safety culture

\section{Balıkesir İli Konaklama Sektörü Çalışanlarında İş Güvenliği Kültürüi: NOSACQ-50 Araştırması}

$\ddot{O} z$

Bu araştırmanın amacı konaklama sektöründe güvenlik kültürü düzeyi ve güvenlik kültürünü etkileyen faktörlerin neler olduğunu incelemektir. Bu çalışmada ölçüm aracı olarak NOSAC-Q-50 güvenlik kültürü anketi 200 konaklama sektörü çalışanına uygulanarak katılımcıların iş sağlı̆̆ ve güvenliği (İSG) kültürü seviyesi incelenmiştir. Toplanan veriler, SPSS 25 programında değerlendirilmiş ve altı adet araştırma sorusu analiz edilmiştir. Katılımcıların iş sağlı̆̆ ve güvenliği külttürü anketine verdiği cevaplar ile araştırma soruları arasındaki ilişkinin anlamlılık düzeyini belirlemek için bağımsız-t testi ve tek yönlü varyans analizi yapılmıştır. Güvenlik kültürü anketinden elde edilen sonuçlar yöneticilerin İSG farkındalığı, çalışanların İSG farkındalığı ve çalışanların İSG eğitim bilgisi olarak 3 kategori altında ele alınmıştır. Yönetimin İSG farkındalığı ile çalışanların İSG farkındalığı puanları arasında pozitif ilişki tespit edilmiştir. Ayrıca çalışanların İSG farkındalıkları ile mesleki deneyimleri arasında istatistikçe anlamlı bir ilişki saptanmıştır.

Anahtar Kelimeler: Konaklama sektörü, NOSAC-Q50 anketi, iş güvenliği, güvenlik kültürü,

\section{INTRODUCTION}

"Safety culture" is a concept that has been frequently dealt with in the field of occupational safety (Muñiz et al., 2009; Ajslev et al., 2017). This concept has been addressed by many occupational groups and disciplines to prevent and reduce occupational accidents (Nielsen et al., 2008; Antonsen, 2009).The human factor in the workplace has a considerable influence on the performance of the work (Nielsen et al., 2008; Antonsen, 2009). Safety culture should be maintained for the employees to work more safely and in a healthy way, which increases their motivation (Cooper, 2000; Wiegmann et al., 2009). In terms of occupational health and safety, embracing the safety culture in the work place depends on the management and personnel (Glendon and Stanton, 2000; Khan et al., 2018). Although the state, employers, and unions fulfil their duties regarding occupational health and safety, the desired results cannot be achieved if the safety culture is not adopted by the employees (Gadd and Collins, 2002). For this reason, the rules in the 
working environment must be followed, sufficient knowledge about tools and machines must be obtained, and the utilization of the training activities must be maximized (Fleming and Leveson, 2015).

One of the most important elements that stimulate the economy in Turkey is tourism. Turkey has hosted many cultures and civilizations and is surrounded by sea on three sides. Turkey is at the forefront in terms of cultural and historical tourism. Turkey was the sixth country in the list with 46 million tourists as the World Tourism Organization (UNWTO) announced in 2018 (URL-1). According to the World Travel and Tourism Council (WTTC) statistics, in 2015, 7.2 million people were employed directly and indirectly in the tourism industry worldwide in Turkey. The employment rate increased by $2.6 \%$ on the sector basis and the number of personnel working in the tourism sector reached 284 million. One of 11 employees was employed in the tourism and travel industry. According to the 2015 report of WTTC, 127 of 184 countries experienced sectoral growth. According to the report, there was a growth of $7.9 \%$ in Southeast Asia, 7.4\% in South Asia, $5.9 \%$ in the Middle East, $51 \%$ in the Caribbean Islands, 3.3\% in Sub-Saharan Africa, 3.1\% in North America, $2.5 \%$ in Europe, $2.1 \%$ in Northeast Asia, $1.5 \%$ in Latin America and $1.4 \%$ in North Africa in the field of travel and tourism (URL-1). With the increase in employment, many employees face work accidents due to insufficient occupational safety measures and a lack of safety culture. It is necessary to raise the awareness of occupational health and safety culture in the field of tourism.

Akalp and Karadeniz (2013) investigated the relationship between safety culture and management behavior, and stated that the role of management is important among all policies and measures implemented to ensure the safety culture. Dursun (2013) investigated the effect of occupational safety culture on the safe behaviors of employees and found a significant relationship between the safety culture perception and safe behavior of employees in the manufacturing industry. Üngüren and Koç (2016) examined the effect of occupational health and safety practices on organizational trust in accommodation sector and found that there are positive significant relationships between occupational health and safety practices and organizational trust. Can and Hüseyinli (2017) examined the effect of occupational health and safety culture on the safe behavior of hotel employees in 4 and 5 star hotels in Antalya Region. In the study, they found that employees 'perceptions of safety culture had a positive and significant relationship on their tendency to safe behavior, and they concluded that activities that would increase employees' perceptions of safety culture would increase their tendency towards safe behavior during work.

In this study, NOSACQ-50 (Nordic Occupational Safety Climate Questionnaire) questionnaire was applied as the measurement tool to determine the level of occupational health and safety culture of workers in accommodation sector.

\section{MATERIAL AND METHODS}

This research was carried out in four hotels having three or more stars in Balıkesir Province in Turkey. In the study, the NOSACQ-50 questionnaire was applied to 200 randomly selected employees. The employees participated to the survey were working in the front desk, food and beverage services, housekeeping and support services. In addition to the NOSACQ-50, 6 questions were added to identify the socio-demographic characteristics and occupational accident experiences of employees. The NOSACQ50 questionnaire was developed by a group of Scandinavian occupational safety researchers (Kines et al., 2011) and consists of 50 questions and has a 4point Likert scale $(1=$ Strongly Disagree, $2=$ Disagree, $3=$ Undecided and 4=Agree). NOSACQ-50 is a tool to evaluate occupational safety culture interventions and available in over 40 language versions. The survey based on organizational and safety climate theory, psychological theory, previous empirical research, empirical results acquired through international studies, and a continuous development process (Kines et al., 2011). NOSACQ-50 consists of 50 items across seven dimensions in Kines (2011) study like shared perceptions of: 1) management safety priority, commitment and competence; 2) management safety empowerment; and 3) management safety justice; as well as shared perceptions of 4) workers' safety commitment; 5) workers' safety priority and risk non-acceptance; 6) safety communication, learning, and trust in coworkers' safety competence; and 7) workers' trust in the efficacy of safety systems. In this study some of the dimensions are combined and three sub dimensions as the OHS awareness of the management, OHS awareness of the employees, and OHS training knowledge of the employees were 
analysed. The first 22 questions analyse the OHS awareness of the management. The questions between 23 and 43 analyse the OHS awareness of the employees. The last 6 questions analyse OHS training knowledge of the employees.

The Cronbach alpha value of the questionnaire is 0.76 as a reliability score. Six research questions were developed and analysed. The correlation levels of the research questions were investigated upon the survey data. Since the distribution was found to be normal, the results were examined with t- test or one-way analysis of variance (ANOVA). The required written permissions were obtained from the hotels before the research. Furthermore, the ethics committee approval (No: 12, 61351342/2019-651) was taken from Uskudar University.

\section{RESULTS AND DISCUSSION}

The distribution of the socio-demographic variables of the participants is shown in Table 1. Most of the participants are between the ages of 2636. It is found that more than half are high school graduates or have less than a high school diploma according to the education levels of the participants. The data related to the occupation of the participants show that most of the staff is the front office and support personnel. Most of the participants are married. It is found that $67 \%$ of the participants have professional experience below 10 years, and 33\% have 11 years and above.

As seen in Figure 1, it is found that $38 \%$ of $(n=$ 76) participants had a work accident experience and $62 \%(n=124)$ had no work accident. More than half of the accommodation sector personnel have not experienced an occupational accident before. Still, this rate is considered high for a workplace classified as less dangerous according to NACE standards (Statistical Classification of Economic Activities in the European Community).

In Table 2, the Pearson correlation analysis are shown, and a statistically significant positive relationship is indicated between the scores of the OHS awareness of the management and OHS awareness of the employees $(p=0.004)$. The result shows that as the OHS awareness of the management increases, so does the OHS awareness of the employees. Likewise, a statistically significant positive relationship is found between the management's OHS awareness and OHS training
Table 1. Demographic characteristics of the participants

\begin{tabular}{|c|c|c|}
\hline Individual Characteristics & $\mathbf{N}$ & $\%$ \\
\hline \multicolumn{3}{|l|}{ Age } \\
\hline $18-25$ & 51 & 25.5 \\
\hline $26-35$ & 52 & 26 \\
\hline $36-45$ & 72 & 36 \\
\hline $46-55$ & 25 & 12.5 \\
\hline \multicolumn{3}{|l|}{ Education Level } \\
\hline High School or Lower & 115 & 57.5 \\
\hline University or Above & 85 & 42.5 \\
\hline \multicolumn{3}{|l|}{ Department } \\
\hline Front Desk & 44 & 22 \\
\hline Food and Beverage Services & 60 & 30 \\
\hline Housekeeping & 43 & 21.5 \\
\hline Support Services & 53 & 26.5 \\
\hline \multicolumn{3}{|l|}{$\begin{array}{c}\text { Professional Experience } \\
\text { (Year) }\end{array}$} \\
\hline $0-5$ & 67 & 33.5 \\
\hline $6-10$ & 67 & 33.5 \\
\hline $11-15$ & 44 & 22 \\
\hline 16 and Higher & 22 & 11 \\
\hline \multicolumn{3}{|l|}{ Marital Status } \\
\hline Married & 123 & \\
\hline Single & 77 & \\
\hline \multicolumn{3}{|l|}{$\begin{array}{c}\text { Experience of an Occupational } \\
\text { Accident }\end{array}$} \\
\hline Yes & 76 & 38 \\
\hline No & 124 & 62 \\
\hline
\end{tabular}

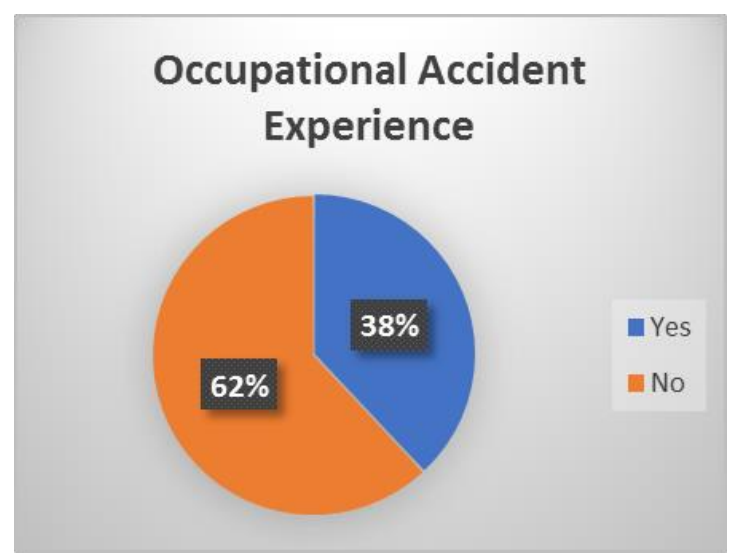

Figure 1. Occupational accident experience of the participants

knowledge scores of the employees $(p=0.001)$. So, as the OHS awareness of the management increases, the employees' knowledge of OHS training also develops. A statistically significant relationship is 
found between the OHS awareness and OHS training knowledge scores of the employees $(\mathrm{p}<0.001)$.
As a result, as the OHS awareness of the employees increases, so does the OHS training knowledge.

Table 2. Correlation results

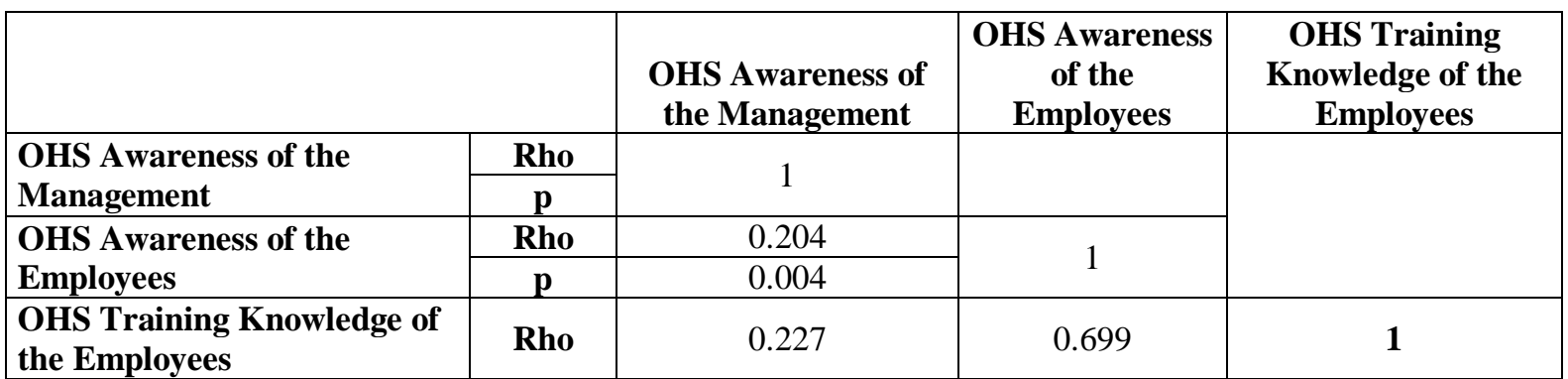

Research question 1: Is there a significant difference between the occupational health and safety awareness and education levels of the accommodation sector employees?

As seen in Table 3, the OHS awareness of the management and the employees, and the employees' OHS training knowledge are compared to the education levels. The OHS awareness of the management has a statistically significant difference. The OHS awareness is higher in the management with a university education or above than those who had a high school education or below $(\mathrm{p}=0.022)$. The OHS awareness of the employees do not show a statistically significant difference regarding their education levels $(p=0.762)$. Similarly, the OHS training knowledge of the employees do not show a statistically significant difference compared to their education levels $(p=0.331)$. In the literature,
Çelikkalp et al. (2017) states that OHS awareness increased significantly with the training provided, and the knowledge and awareness levels of the personnel.

Research question 2: Is there a significant difference between the OHS training knowledge and education levels of employees?

No significant difference was found between employees' OHS training knowledge and the level of education of employees. When the percentage distribution of OHS education information is examined in terms of education levels, it was found that 115 employees have the degree of high school and below, 85 employees have the degree of university and above. In the literature Kılkış and Demir (2012) was found that there is a significant difference between OHS training information and education levels of employees.

Table 3. Comparison of OHS awareness of management, OHS awareness of employees and OHS training knowledge according to education levels of employees

\begin{tabular}{|c|c|c|c|c|c|}
\hline \multicolumn{2}{|c|}{ Education Level } & $\mathbf{N}$ & Average & $\mathbf{t}$ & $\mathbf{p}$ \\
\hline \multirow{2}{*}{$\begin{array}{l}\text { OHS Awareness of } \\
\text { Management }\end{array}$} & $\begin{array}{c}\text { High School or } \\
\text { Lower }\end{array}$ & 115 & 53.23 & \multirow{2}{*}{-2.308} & \multirow{2}{*}{0.022} \\
\hline & University or Above & 85 & 58.44 & & \\
\hline \multirow{2}{*}{ OHS Awareness of Employees } & $\begin{array}{l}\text { High School or } \\
\text { Lower }\end{array}$ & 115 & 75.80 & \multirow{2}{*}{-0.303} & \multirow{2}{*}{0.762} \\
\hline & $\begin{array}{l}\text { University and } \\
\text { Above }\end{array}$ & 85 & 76.11 & & \\
\hline \multirow{2}{*}{$\begin{array}{l}\text { OHS Training Knowledge of } \\
\text { Employees }\end{array}$} & $\begin{array}{l}\text { High School or } \\
\text { Lower }\end{array}$ & 115 & 20.82 & \multirow{2}{*}{-0.946} & \multirow{2}{*}{0.331} \\
\hline & $\begin{array}{l}\text { University and } \\
\text { Above }\end{array}$ & 85 & 21.17 & & \\
\hline
\end{tabular}


Research question 3: Is there a significant difference between the OHS training knowledge and professional experiences of the employees in the accommodation sector?

In Table 4, the relationship between OHS awareness of the managers, OHS awareness of the employees, and OHS training knowledge of the employees are compared to the participants' professional experience with ANOVA. There is a statistically significant relationship between the OHS awareness of the employees and their professional experience $\left(\mathrm{F}_{(3.196)}=2.876, \mathrm{p}=0.036\right)$. The Tukey's test is applied to determine the source of the difference, and a significant difference is found between those with $0-5$ years of professional experience and those with 6-10 years, $11-15$ years and more than 16 years of professional experience $(\mathrm{p}=$ $0.040 ; \mathrm{p}=0.038 ; \mathrm{p}=0.026 ; \mathrm{p}=0.021$ respectively). Correspondingly, a statistically significant relationship is found between the OHS training knowledge and professional experience of the employees $\left(\mathrm{F}_{(3.196)}=6.621, \mathrm{p}<0.001\right)$. When the Tukey's test is applied, a significant difference is found between those with 0-5 years of professional experience and those with 6-10 years, $11-15$ years and more than 16 years of professional experience $(\mathrm{p}=$ $0.025 ; \mathrm{p}=0.019 ; \mathrm{p}=0.017 ; \mathrm{p}=0.002$, respectively). A similar conclusion has been found in the literature between OHS training knowledge and professional experience. Eren and Nebioğlu (2017) showed a significant difference as OHS training information increases professional experience

Research question 4: Is there a significant difference between the OHS awareness and professional experience of the management in the accommodation sector?

As a result of the ANOVA test, no statistically significant relationship was found between the OHS awareness of management and the professional experiences $\left(\mathrm{F}_{(3.196)}=1.292, \mathrm{p}=0.278\right)$. In the literature, the OHS awareness of the management and the professional experiences are directly proportional (Muñiz et al., 2009). Since $70 \%$ of the personnel participating in this study have less than 10 years of experience, this could be the reason of the fact that there is no significant difference in the study.

Table 4. Comparison of OHS awareness of management, OHS awareness of employees and OHS training knowledge of employees according to the professional experience

\begin{tabular}{|c|c|c|c|c|}
\hline Groups & $\begin{array}{l}\text { Professional } \\
\text { Experience (Years) }\end{array}$ & $\mathbf{N}$ & $\mathbf{F}$ & $\mathbf{p}$ \\
\hline OHS Awareness of Management & $\begin{array}{l}\text { (1) } 0-5 \text { Years } \\
\text { (2) } 6-10 \text { Years } \\
\text { (3) } 11-15 \text { Years } \\
\text { (4) } 16 \text { Years and Above }\end{array}$ & $\begin{array}{l}67 \\
67 \\
44 \\
22 \\
\end{array}$ & 1.292 & 0.278 \\
\hline OHS Awareness of Employees & $\begin{array}{l}\text { (1) } 0-5 \text { Years } \\
\text { (2) } 6-10 \text { Years } \\
\text { (3) } 11-15 \text { Years } \\
\text { (4) } 16 \text { Years and Above } \\
\end{array}$ & $\begin{array}{l}67 \\
67 \\
44 \\
22 \\
\end{array}$ & 2.876 & 0.036 \\
\hline $\begin{array}{l}\text { OHS Training Knowledge of } \\
\text { Employees }\end{array}$ & $\begin{array}{l}\text { (1) } 0-5 \text { Years } \\
\text { (2) } 6-10 \text { Years } \\
\text { (3) } 11-15 \text { Years } \\
\text { (4) } 16 \text { Years and Above }\end{array}$ & $\begin{array}{l}67 \\
67 \\
44 \\
22 \\
\end{array}$ & 6.621 & 0.001 \\
\hline
\end{tabular}

Research question 5: Is there a significant difference between the OHS training information of employees and their ages?

In Table 5, the relationship between the OHS awareness of the management, OHS awareness of employees, and OHS training knowledge of the employees are compared to the age factor with the one-way ANOVA. However, there is no statistically significant relationship between the groups and ages.
Similarly, Ulutaşdemir et al. (2015) was found no significant difference between OHS training information and age.

Research question 6: Is there a significant difference between the OHS awareness of employees and occupational accident experiences?

In Table 6, the OHS awareness of the management, OHS awareness and OHS training knowledge of the employees are compared and to 
occupational accident experiences. As a result, no statistically significant difference is found. When the rates of occupational accidents were examined, it was observed that 76 employees had occupational accident experience and 124 employees did not.

Table 5. Comparison of the OHS awareness of management, OHS awareness of employees and ohs training knowledge of employees according to the age

\begin{tabular}{|l|l|l|l|l|}
\hline Groups & Age & N & F & p \\
\hline \multirow{4}{*}{ OHS Awareness of Management } & (1) $18-25$ & 51 & & \\
& (2) $26-35$ & 52 & 1.065 & 0.365 \\
& (3) $36-45$ & 72 & & \\
& (4) $46-55$ & 25 & & \\
\hline \multirow{4}{*}{ OHS Awareness of Employees } & (1) $18-25$ & 51 & & \\
& (2) $26-35$ & 52 & 1.165 & 0.324 \\
& (3) $36-45$ & 72 & & \\
& (4) $46-55$ & 25 & & \\
OHS Training Knowledge of & (1) $18-25$ & 51 & & \\
Employees & (2) $26-35$ & 52 & 2.067 & 0.106 \\
& (3) $36-45$ & 72 & & \\
\hline
\end{tabular}

Table 6: Comparison of OHS awareness of management, OHS awareness of employees and ohs training knowledge of employees according to the occupational accident experiences

\begin{tabular}{|c|c|c|c|c|c|}
\hline \multicolumn{2}{|c|}{ Experience of Occupational Accident } & $\mathbf{N}$ & Average & $\mathbf{t}$ & $\mathbf{p}$ \\
\hline \multirow{2}{*}{$\begin{array}{l}\text { OHS Awareness of } \\
\text { Management }\end{array}$} & Yes & 76 & 57.18 & \multirow{2}{*}{-0.015} & \multirow{2}{*}{0.918} \\
\hline & No & 124 & 57.16 & & \\
\hline \multirow{2}{*}{ OHS Awareness of Employees } & Yes & 76 & 75.18 & \multirow{2}{*}{-1.179} & \multirow{2}{*}{0.240} \\
\hline & No & 124 & 76.40 & & \\
\hline \multirow{2}{*}{$\begin{array}{l}\text { OHS Training Knowledge of } \\
\text { Employees }\end{array}$} & Yes & 76 & 20.60 & \multirow{2}{*}{-1.588} & \multirow{2}{*}{0.114} \\
\hline & No & 124 & 21.20 & & \\
\hline
\end{tabular}

\section{CONCLUSION}

In the accommodation sector, the job requires teamwork, intensive labour, long and stressful working hours. The basis of the accommodation sector is providing the guests with a service that is good, meticulous, healthy, safe, and of the best quality (Pronovost and Sexton, 2005; Runefors and Borell, 2014). All departments in the accommodation sector (front office, food and beverage services, housekeeping, and support services) play an important role in ensuring the satisfaction of customers as well as helping the businesses leave a positive image on them (Wang and Liu, 2019). Since the accommodation sector workers are working dynamically in shifts, they are open to the risk of injury and loss of life as a result of the accident hazards (Parker et al., 2006). Occupational Health and Safety Law No. 6331, which was adopted in 2012 and entered into force in 2013, the regulations related to this law, and OHS professionals, have played an effective role in the regulation of OHS practices. The concept of safety culture is important in the transfer of knowledge to protect the accommodation sector employees from the risks and the potential hazards they will face during their professional careers.

Consequently, the results show that in the accommodation sector, as the management' OHS awareness increases, the OHS awareness of the employees is found to be increasing as well. So, it is recommended to increase the OHS training of the management and the management staff, in order to raise the OHS awareness and to pass the awareness onto the employees. Thus, the level of safety culture will increase. Positive safety culture levels of the accommodation sector employees will have a positive effect on reducing occupational accidents and performing the duties safer and healthier. Moreover, OHS trainings could be prepared specific and special for the accommodation sector, and OHS professionals and workers could have special OHS trainings for this sector 
Since the accommodation sector is in the less dangerous class, the hotel managements usually demand the support of OHS professionals. Effective and healthy communication between OHS professionals and hotel management will have benefits in terms of the safety culture.

The survey results show that there is a statistically significant relationship between the OHS awareness of the employees and their professional experience. Establishing OHS awareness, having more frequent training will have positive outcomes.

Future researches could be done across Turkey, covering more than one city and region so that it will be more significant. By providing training and practices that will instil a more specific content on the safety culture for the accommodation sector employees, awareness can be raised, and thus, the improvement of the safety culture can be ensured.

\section{ACKNOWLEDGMENTS}

This article is derived from the master thesis of Arda Yılmaz at Üsküdar University, Institute of Health Sciences.

\section{CONFLICT OF INTEREST}

The author(s) declared no potential conflicts of interest with respect to the research, authorship, and/or publication of this article.

\section{RESEARCH AND PUBLICATION ETHICS STATEMENT}

The authors declare that research and publication ethics are followed in this study.

\section{REFERENCES}

Ajslev, J., Dastjerdi, E.L., Dyreborg, J., Kines, P., Jeschke, C.K., Sundstrup, E., Jakobsen, M.D., Fallentin, N., Andersen, L.L., 2017. Safety climate and accidents at work: Cross-sectional study among 15,000 workers of the general working population. Safety Science, 91:320-325.

Akalp, G., Yamankaradeniz, N., 2013. İşletmelerde güvenlik kültürünün oluşumunda yönetimin rolü ve önemi. Sosyal Güvenlik Dergisi, 3(2):96-109.

Antonsen, S., 2009. Safety culture assessment: A mission impossible?. Journal of Contingencies and Crisis Management, 17(4):242-254.

Can, M., Hüseyinli, N., 2017. Çalışma hayatında iş sağlı̆̆ 1 ve güvenliği kültürü ve otel çalışanlarının güvenli davranışlarının incelenmesi. Atatürk Üniversitesi Sosyal Bilimler Enstitüsü Dergisi, 21(4):1397-1420.
Çelikkalp, Ü., Saraçoğlu, G., Tokuç, B., 2015. "Increase of knowledge level of nursing students about occupational health and safety". Namık Kemal Medical Journal, 5(1):36-43.

Cioni, M., Savioli, M., 2015. Safety at the workplace: accidents and illnesses. Work, Employment And Society, 30(5):858-875.

Cooper, M.D., 2000. Towards a model of safety culture. Safety Science, 36(2):111-136.

Dursun, S., 2013. İş güvenliği kültürünün çalışanların güvenli davranışları üzerine etkisi. Sosyal Güvenlik Dergisi, 3(2):61-75.

Eren, R., Nebioğlu, O., 2017. Knowledge levels on food safety of employees working in hotel enterprises' kitchen: the example of Alanya. Journal of Multidisciplinary Academic Tourism, 1(2):47-64.

Fleming, H., Leveson, N., 2015. Integrating systems safety into systems engineering during concept development. INCOSE International Symposium, 77:33-407.

Gadd, S., Collins, A.M., 2002. Safety culture: A review of the literature. Sheffield: Health \& Safety Laboratory.

Glendon, A., Stanton, N., 2000. perspectives on safety culture. Safety Science, 34:193-214.

Khan, N., Ilyas, M., Ahmad, I., 2018. Impact of ethical leadership on organizational safety performance: the mediating role of safety culture and safety consciousness. Ethics \& Behavior, 628-643.

Kılkış, İ., Demir, S., 2012. İşverenin iş sağlığı ve güvenliği eğitimi verme yükümlülüğü üzerine bir inceleme. Çalışma İlişkileri Dergisi, 3(1):23-47.

Kines, P., Bergh, M., Shahriaria, M., 2011. Nordic safety climate questionnaire (NOSACQ-50): A new tool for diagnosing occupational safety climate. International Journal of Industrial Ergonomics, 41:634-646.

Muñiz, B.F., Peón, J.M., Ordás, J.V., 2009. Relation between occupational safety management and firm performance. Safety Science, 47(7):980-991.

Nielsen, K.J., Rasmussen, K., Glasscock, D., Spangenberg, S., 2008. Changes in safety climate and accidents at two identical manufacturing plants. Safety Science, 46:440-449.

Parker, D., Lawrie, M., Hudson, P., 2006. A framework for understanding the development of organisational safety culture. Safety Science, 44(6):551-562.

Pronovost, P., Sexton, B., 2005. Assessing safety culture: guidelines and recommendations. Quality and Safety in Health Care, 14:231-233.

Runefors, M., Borell, J., 2014. Relationships between safety culture aspects - a work process to enable interpretation. Marine Policy, 44:179-186.

URL, 1. 2019. https://www.turizmgunlugu.com/2019/09/0 6/turizm-verileri/ Tourism and Travel Newspaper, 6 September 2019. 
Ulutaşdemir, N., Dokur, M., Bayraktar, N., Bostanoğlu, H., Çopur, E., Çolakfakıoğlu, I.,, 2015. An evaluation of occupational health and safety training at a private factory in Gaziantep. Hacettepe University Faculty of Health Sciences Journal, 1.

Üngüren, E., Koç, T.S., 2016. Konaklama işletmelerinde iş sağlığı ve güvenliği uygulamalarının örgütsel güven üzerindeki etkisi. Endüstri İlişkileri ve İnsan Kaynakları Dergisi, 18(2):128-161.

Wang, J., Liu, B., 2019. Risk reduction and adventure tourism safety: An extension of the risk perception attitude framework (RPAF). Tourism Management, 74:247-257.

Wiegmann, D., Zhang, H., Thaden, T.L., Sharma, G., Gibbons, A.M., 2009. Safety culture: An integrative review. The International Journal of Aviation Psychology, 14(2):117-134. 